\title{
T cells migrate to tumour sites after extracorporeal interleukin 2 stimulation and reinfusion in a patient with metastatic melanoma
}

\author{
R.DUMMER, J.C.BECKER, $\dagger$ C.EILLES,* E.SCHÄFER,* W.BÖRNER* AND G.BURG \\ Department of Dermatology. University Hospital Zürich, Gloriastr. 31, CH-8091 Zürich. Switzerland \\ *Department of Nuclear Medicine. University of Würzburg. Josef-Schneider Str. 2. D-8700 Würzburg. Germany \\ †Department of Dermatology. University of Würzburg. Josef-Schneider Str. 2. D-8700 Würzburg. Germany
}

Accepted for publication 2 November 1992

Summary Peripheral blood mononuclear cells (PBMC) were taken by leukapheresis from a patient with melanoma skin metastases and stimulated in vitro using $1000 \mathrm{IU}$ recombinant interleukin $2(\mathrm{IL}-2) / \mathrm{ml}$ to generate lymphokine-activated killer cells (LAK cells). Two-colour immunofluorescence analysis demonstrated an IL-2-induced up-regulation of $\mathrm{CD} 25$ on natural killer cells $\left(\mathrm{CD} 56^{+}\right)$as well as on T lymphocytes $\left(\mathrm{CD}^{+}\right)$. After radiolabelling with indium-111, the cells were reinfused. Gamma-camera imaging revealed an enrichment at the tumour sites. Immunostaining of tumour tissue taken before and after scintigraphy demonstrated $\mathrm{CD} 25^{+} \mathrm{T}$ lymphocytes $\left(\mathrm{CD} 2^{+}, \mathrm{CD} 3^{+}\right)$, but no natural killer cells $\left(\mathrm{CD} 16^{+}, \mathrm{CD} 56^{+}\right)$infiltrating the metastases.

LAK cell enrichment at melanoma metastases in vivo did not involve natural killer cells, but was characterized by increased numbers of activated $\mathrm{T}$ lymphocytes in this patient.

Interleukin 2 (IL-2) was originally designated 'T-cell growth factor' because of its ability to maintain longterm in vitro cultures of T lymphocytes. ${ }^{1}$ It augments the cytotoxic activity of natural killer cells and cytotoxic T cells against a variety of cultured and fresh tumour cells. This enhanced cytotoxicity after brief exposure of peripheral blood mononuclear cells (PBMC) to IL-2 is referred to as lymphokine-activated killer (LAK) cell activity. ${ }^{2}$ 'LAK' does not define a certain cell type, but a functional property which is exerted by a mixture of different cell types. ${ }^{3.4}$

Recently, we reported the successful imaging of melanoma metastases using radiolabelled LAK cells. ${ }^{5}$ The co-operation of a patient with metastatic malignant melanoma allowed us to take sequential biopsies to characterize the trafficking cells during LAK cell scintigraphy.

Correspondence: Dr R.Dummer, Department of Dermatology. University Hospital Zürich, Gloriastr. 31, CH-8091 Zürich. Switzerland.

This work was presented in part at the European Society for Dermatological Research meeting. 4-7 April 1992, at Kensington Town Hall. London, U.K.

\section{Methods}

Patient

A 52-year-old man, suffering from melanoma, with multiple skin and lymph-node metastases, gave written informed consent to LAK cell scintigraphy according to a protocol approved by the Ethical Committee of the University of Würzburg. He allowed biopsies to be taken from a skin metastasis before, and $120 \mathrm{~h}$ after, scintigraphy. Half of each specimen was snap-frozen, and the other half fixed with buffered formalin, embedded in paraffin, and stained with haematoxylin and eosin.

\section{Generation of LAK activity}

Peripheral blood mononuclear cells (PBMC) were collected by a 3-h leukapheresis (Haemonetics V 50). After Ficoll-Hypaque centrifugation. PBMC were cultured in plastic bags (Lifecell culture bags $1000 \mathrm{ml}$, Fenwal) containing RPMI 1640 medium (Gibco, Germany), supplemented with $2 \%$ human serum, antibiotics, and $1000 \mathrm{IU}$ recombinant interleukin 2 (Proleukin, Eurocetus, Frankfurt) for 4 days. 


\section{Immunofluorescence analysis}

Immediately after collection and prior to reinfusion, PBMC were analysed using monoclonal antibodies CD3. CD56, CD25 (Becton Dickinson, San Jose, CA, U.S.A.). They were washed twice with PBS, and then incubated with purified human IgG for $10 \mathrm{~min}$ to inhibit subsequent monoclonal antibody binding to immunoglobulin receptors. Cells $\left(1 \times 10^{6}\right)$ were incubated for 30 min with a first-step antibody. After two washes with HBSS containing $0 \cdot 2 \%$ sodium azide, cells were stained for $30 \mathrm{~min}$ with $\mathrm{Fab}_{2}$ goat anti-mouse IgG FITC conjugate. After two washes, the cells were incubated for 20 min with excess mouse IgG to block free goat antimouse IgG-binding sites. The goat anti-mouse IgG and blocking steps were omitted for samples stained with directly FITC-conjugated monoclonal antibodies. After the blocking step, directly PE-conjugated monoclonal antibody was added, followed 30 min later by two washes. All incubations and washes were performed at $4^{\circ} \mathrm{C}$. Cells were analysed with a FACScan (Becton Dickinson) at 488 and $590 \mathrm{~nm}$. The noise threshold was set to exclude volume signals below those of lymphocytes. All analyses were performed using photomultiplier voltages and gain settings that were standardized using fluorescent calibration beads, and all signals were processed using logarithmic amplification. Fluorochrome-conjugated mouse IgG2a monoclonal antibody controls were used to assess the degree of non-specific antibody binding to each cell preparation.

\section{CR-51 release assay}

Cytotoxic activity of the PBMC was determined in a standard 4-h CR-51 release assay as previously described, ${ }^{2}$ using the erythroblastoma cell line K 562 and the B lymphoblastoid line Raji as target cells. Effector/ target ratios were 40:1 and 10:1. Spontaneous release was assessed by incubating labelled K 562 in medium alone, and total release was evaluated by a solution of sodium dodecyl sulphate. After the supernatants were harvested using a Skatron filter-stick system, radioactivity was measured in a Pharmacia gamma-counter.

Specific lysis (SL) was calculated as:

\section{SL $(\%)=$}

Mean experimental release - mean spontaneous release Mean total release - mean spontaneous release

\section{LAK cell scintigraphy}

After the 4-day, high-dose IL-2 stimulation, PBMC were washed twice and incubated with $7.5 \mathrm{MBq}$ indium-11 i oxine in $4 \mathrm{ml}$ PBS for $15 \mathrm{~min}$ at $37^{\circ} \mathrm{C}$ in an atmosphere of $5 \% \mathrm{CO}_{2}$ in air. After labelling, viability was assessed by trypan blue dye exclusion. PBMC $\left(1 \times 10^{9}\right)$ were transferred into $250 \mathrm{ml}$ normal saline and reinfused within 30 min using a standard blood tubing set containing a $200 \mu \mathrm{m}$ in-line filter. Static gamma-camera imaging was obtained $2 \cdot 5,24,48,96$ and $120 \mathrm{~h}$ after transfusion.

\section{Immunostaining of skin biopsies}

Snap-frozen biopsy specimens were stored at $-70^{\circ} \mathrm{C}$ until use. They were stained by the APAAP technique, ${ }^{6}$ using a panel of monoclonal antibodies. Three hundred mononuclear cells were counted (magnification $\times 400$ ) and the percentage of stained lymphoid mononuclear cells was scored semiquantitatively (Table 1).

\section{Results}

\section{Generation of LAK cells}

The incubation of $1.5 \times 10^{9} \mathrm{PBMC}$ with $1000 \mathrm{IU}$ IL- $2 / \mathrm{ml}$ for 4 days had no detectable influence on the absolute cell number. Viability prior to, and after, the incubation period was $>95 \%$.

\section{Immunofluorescence analysis}

The two-colour immunofluorescence analysis using antibodies against CD25, CD3, and CD56 showed an augmented expression of $\mathrm{CD} 25$ on $\mathrm{CD}^{+}$as well as CD $56^{+}$cells (Fig. 1).

Table 1. Phenotyping of the peritumoral infiltrate in biopsies prior to. and after, LAK-cell scintigraphy $(0$, none positive:,$+ 1-5 \%$ positive: ++ . $5-25 \%$ positive: $+++.25-50 \%$ positive:.$+++>50 \%$ positive peritumoral mononuclear cells)

\begin{tabular}{|c|c|c|c|}
\hline \multirow[b]{2}{*}{ CD cluster } & \multirow[b]{2}{*}{$\begin{array}{c}\text { Predominant } \\
\text { reactivity }\end{array}$} & \multicolumn{2}{|c|}{ Peritumoral infiltrate } \\
\hline & & $\begin{array}{l}\text { Prior to LAK } \\
\text { scintigraphy }\end{array}$ & $\begin{array}{c}\text { After LAK } \\
\text { scintigraphy }\end{array}$ \\
\hline CD2 & T lymphocytes & $+t+t$ & $++t+$ \\
\hline CD3 & T lymphocytes & $++t+$ & ++++ \\
\hline CD4 & T helper & $+t+t$ & $+++t$ \\
\hline CD8 & T suppressor & ++ & ++ \\
\hline CD16 & NK-cells & 0 & 0 \\
\hline CD 56 & NK-cells & 0 & 0 \\
\hline CD25 & IL-2 receptor & 0 & ++ \\
\hline
\end{tabular}


Figure 1. Two-colour FACS analysis demonstrates an increase of $\mathrm{CD} 25$ expression on $\mathrm{T}$ lymphocyte $\left(\mathrm{CD}^{+}\right)$as well as on NKcells $\left(\mathrm{CD}^{2} 6^{+}\right)$after 4 days' incubation with 1000 IU IL-2. The numbers in the corners indicate the percentage of cells. The numbers in the right upper corners indicate the percentage of double-positive cells.
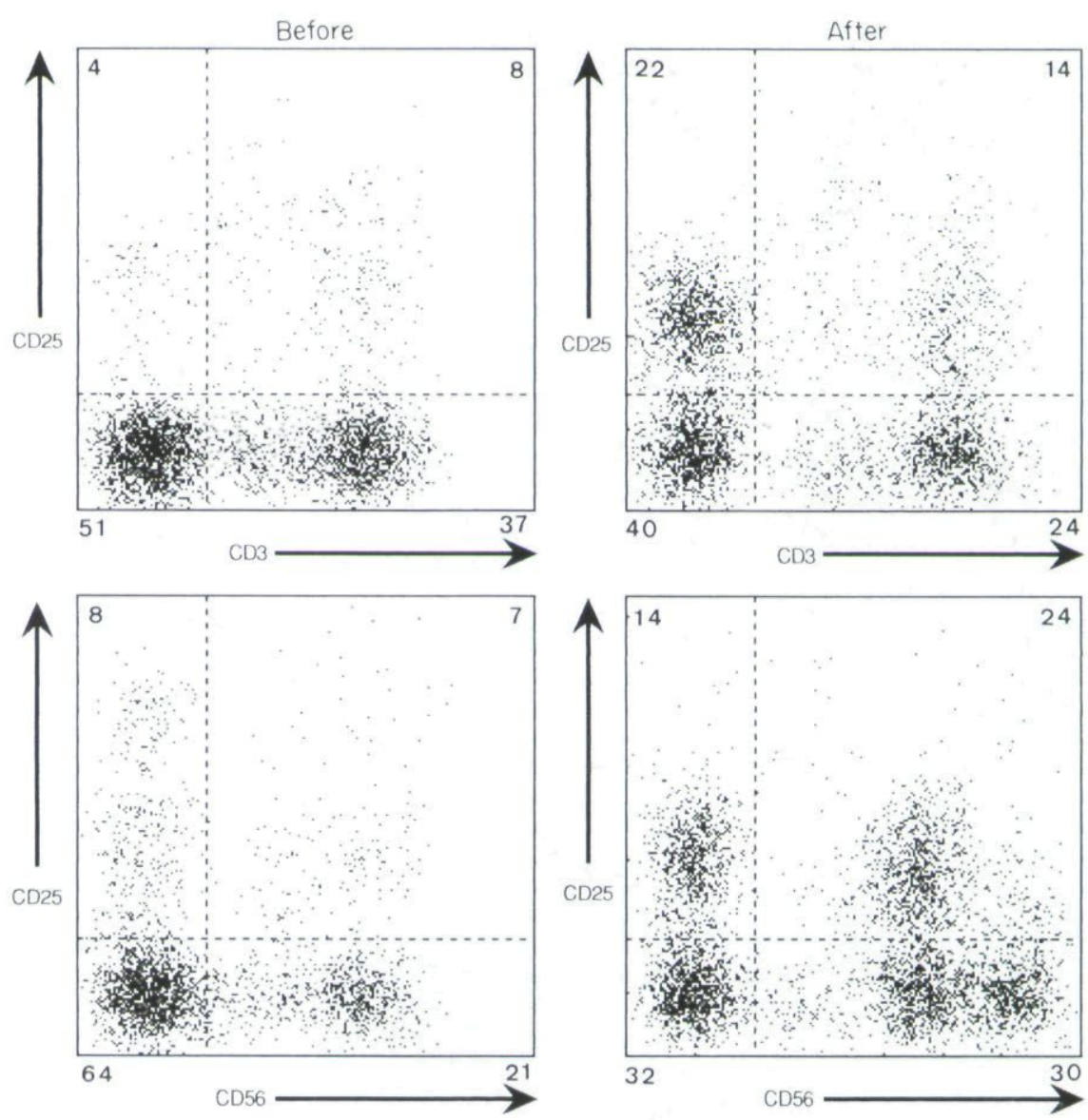

\section{CR-51 release assay}

The incubation of PBMC with $1000 \mathrm{IU}$ IL- $2 / \mathrm{ml}$ resulted in an enhancement of cytotoxicity from $43 \cdot 7$ to $57 \cdot 3 \%$ SL for an effector/target ratio of 10:1 using the NK cell target K 562. Basic SL of Raji cells was 17.9\% (effector/ target ratio $40: 1$ ) and $4.9 \%$ (effector/target ratio 10:1). After IL-2 incubation, SL increased to $40 \cdot 2 \%$ (effector/ target ratio $40: 1$ ) and $21 \cdot 4 \%$ (effector/target ratio $10: 1)$.

\section{LAK cell scintigraphy}

After a 4-day culture in the presence of IL-2, 1.0 $\times 10^{9}$ cells were labelled with $7 \cdot 5 \mathrm{MBq}$. Prior to reinfusion, the cells gained an activity of $5.6 \mathrm{MBq}$ (labelling efficacy $75 \%$, viability $>95 \%$ ). The infusion of the radiolabelled cells was well tolerated. Transient fever (maximum $38.5^{\circ} \mathrm{C}$ ) did not require specific treatment. Reinfused cells migrated primarily to the lungs, liver and spleen $(2.5 \mathrm{~h}$ after reinfusion). After $24 \mathrm{~h}$, the liver and spleen showed a slight increase in activity, whereas the amount of activity in the lungs decreased. After $48 \mathrm{~h}$, multiple lymph-node and subcutaneous localization was demonstrated, corresponding well to tumour sites detected by CT-scan. One-hundred and twenty hours post-infusion, radioactivity was still clearly present in the metastases (Fig. 2).

\section{Immunostaining of skin biopsies}

The biopsies taken prior to therapy and from a scintigraphically positive skin metastasis $120 \mathrm{~h}$ after reinfusion of radiolabelled LAK cells were both stained with a panel of monoclonal antibodies (Table 1). Because the reactive cells accumulate in clusters around the tumour tissue, it was impossible to quantify the lymphocytes in both biopsies. There was no qualitative change in the distribution of cells. However, an increase of CD25 expression was observed in representative fields. In addition, the tumour cells expressed intercellular adhesion molecule-1 and HLA-DR. 

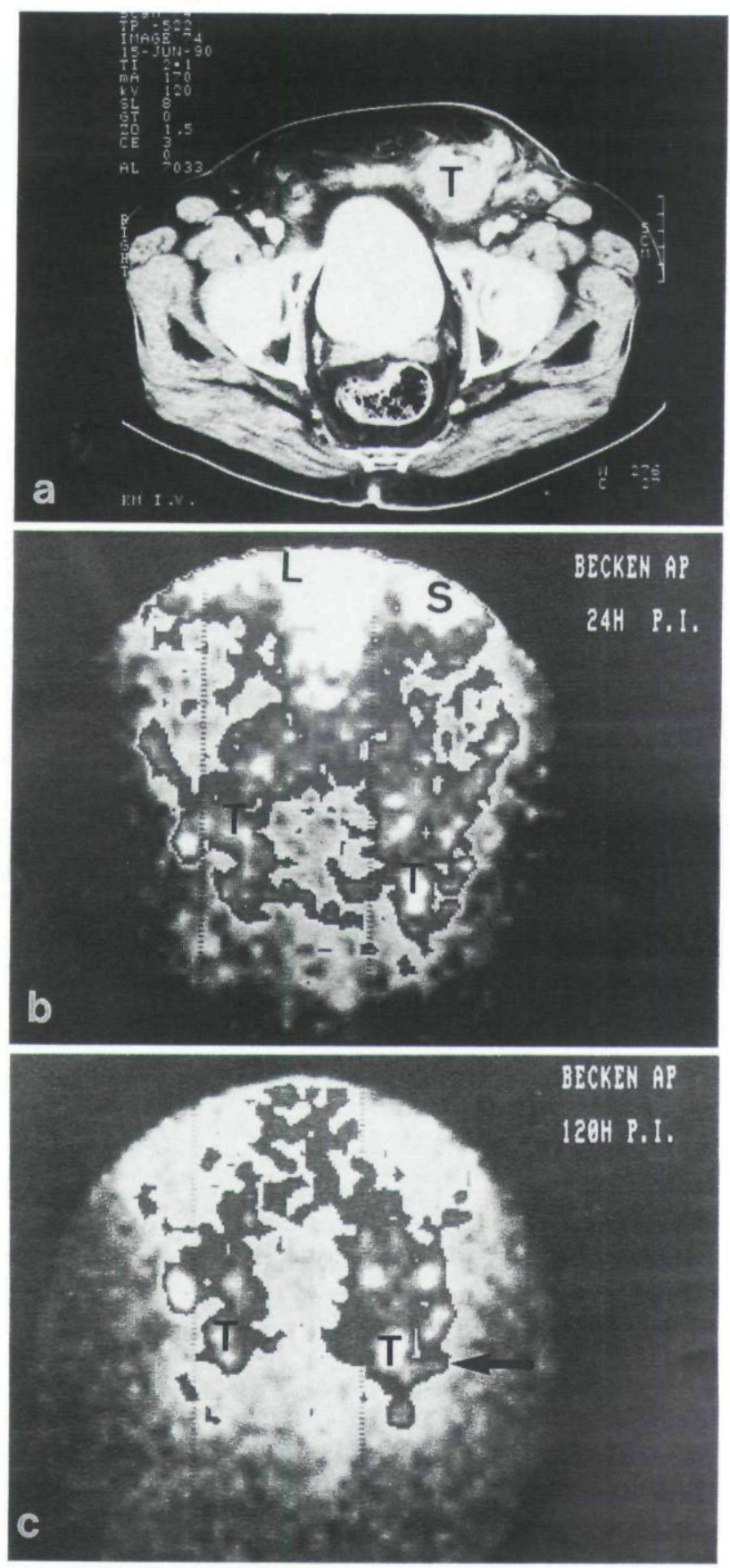

Figure 2. Tumour localization of a metastatic tumour ( $\mathrm{T}$ ) in the lower abdomen shown on the CT scan (a) and by scintiscan (b and c). (b) was taken $24 \mathrm{~h}$. and (c) $120 \mathrm{~h}$ after reinfusion of radiolabelled LAK-cells. (b) shows activity in the liver (L), spleen (S), spine, and tumour tissues (T). In (c), the liver and spleen have cleared, but there is still activity at the tumour sites ( $\mathrm{T}$ ).

\section{Discussion}

The clinical application of interleukin 2 in immunotherapy resulted in new approaches for adoptive cell transfer using LAK cells, ${ }^{4}$ A (adherent) LAK cells, ${ }^{7}$ tumour-infiltrating lymphocytes, ${ }^{8}$ and tumour-activated lymphocytes. ${ }^{9}$ Immunotherapies using interleukin 2 are capable of inducing tumour regression. However, the mechanisms still remain unclear. The augmentation of cell-mediated cytotoxicity is thought to be a major effect of IL-2 administration in vivo, but it is unclear whether cytotoxic cells are able to migrate to tumour sites, and which cytotoxic cell types are involved in this cellular traffic.

Although some studies have failed to demonstrate aggregation of radiolabelled LAK cells in metastatic cancer, ${ }^{10}$ or have shown only poor enrichment at the tumour sites in comparison with tumour-antigen-sensitized killer cells, ${ }^{11}$ LAK cell homing without additional infusion of IL- 2 was recently demonstrated in metastatic melanoma. ${ }^{5}$

As LAK cells consist of a heterogeneous mixture of different cell types which are defined by their functional ability to lyse NK-resistant target cells, we tried to ascertain which cell population includes the migrating cells. A co-operative patient with extensive skin metastases gave us the unique opportunity to study the cellular traffic in vivo.

The stimulation of this patient's PBMC induced augmented lytic activity against the NK-sensitive target cell line K 562, and against NK-resistant Raji cells. Twocolour immunofluorescence analysis revealed an increased expression of $\mathrm{CD} 25$ (low-affinity IL-2 receptor) on $\mathrm{CD}^{+}{ }^{+} \mathrm{T}$ lymphocytes as well as $\mathrm{CD} 56^{+}$natural killer cells, ${ }^{12.13}$ demonstrating the activated status of these cell types.

After radiolabelling with indium-111 (half-life $2 \cdot 8$ days) and reinfusion into the patient via a peripheral vein, we observed the common cellular traffic, with aggregation of cells in the lungs, liver and spleen. Localization in the tumour metastases also occurred. detectable $48 \mathrm{~h}$ post-infusion, and still present after 120 h. At this latter time-point, radioactivity had cleared from the liver, lungs and spleen.

In skin biopsies taken from scintigraphically documented LAK cell infiltrated tissue, we were not able to detect $\mathrm{CD} 56^{+}$cells. No qualitative change in the peritumoral infiltrate was found in this tissue. The only significant change was an increase of $\mathrm{CD} 25$ expression. These findings suggest an influx of activated T lymphocytes, and might depend on conformational changes of the leucocyte function antigen (LFA-1) molecule associated with the activation. ${ }^{14}$ However, because LFA-1 is expressed by virtually all leucocytes, including $\mathrm{T}$ lymphocytes and NK cells, ${ }^{15}$ it remains unclear why no 
CD $56^{+}$NK cells were found in the skin biopsies. One explanation could be a sequestration of NK cells in the lungs. ${ }^{16}$ This would correspond well with reports about aggregation of natural killer cells in a regressing pulmonary metastasis, induced by IL-2 administration and intravenous LAK cell transfer via a central line, ${ }^{17}$ and effective immunotherapy using LAK-application into the hepatic artery in a patient with HLA-DR liver melanoma metastases. ${ }^{18}$ In both cases LAK-cell therapy induced tumour regression in an adjacent organ directly reachable by the transfused cells without relevant dilution. Therefore, the adoptive cell transfer in both cases can be interpreted as a locoregional treatment.

With regard to the regression of metastases during systemic IL-2 therapy plus adoptive cell transfer, a positive correlation was found between T lymphocyte infiltrate. HLA-DR expression and response. ${ }^{19}$ HLA-DR expression seems to be an important precondition for IL-2-induced tumour regression. In our patient, the melanoma cells expressed HLA-DR as well as intercellular adhesion molecule-1. Possibly, these molecules were involved in the accumulation of transferred $\mathrm{T}$ cells in this particular patient.

\section{Acknowledgments}

The authors wish to thank I.Grelle, H.Jahn and C.Pietzsch for their excellent technical assistance.

\section{References}

1 Morgan DA. Ruscetti FW, Gallo R. Selective in vitro growth of T lymphocytes from normal human bone marrows. Science 1976: 193: $1007-8$.

2 Grimm EA, Mazumder A, Zhang HZ, Rosenberg SA. Lymphokineactivated killer cell phenomenon. Lysis of natural killer-resistant fresh solid tumor cells by interleukin 2-activated autologous human peripheral blood lymphocytes. I Exp Med 1982: 155: 1823-41.

3 Phillips JH. Lanier LL. Dissection of the lymphokine-activated killer phenomenon. Relative contribution of peripheral blood natural killer cells and T lymphocytes to cytolysis. J Exp Med 1986: 164: 814-25.

4 Dummer R. Welters H, Keilholz U et al. Interleukin 2: immunologischer Hintergrund und klinische Anwendung in der Tumortherapie. Hautarzt 1990: 41: 53-5.
5 Schäfer E. Dummer R. Eilles Cet al. Imaging pattern of radiolabelled lymphokine-activated killer cells in patients with metastatic malignant melanoma. Eur / Nucl Med 1991: 18: 106-10.

6 Cordell JL. Falini B. Erber WN et al. Immunoenzymatic labeling of monoclonal antibodies using immune complexes of alkaline phosphatase and monoclonal anti-alkaline phosphatase (APAAP complexes). J Histochem Cytochem 1984: 32: 219-29.

7 Melder RJ. Whiteside TL. Vujanovic NL et al. A new approach to generating antitumor effectors for adoptive immunotherapy using human adherent lymphokine-activated killer cells. Cancer Res 1988: 48: 3461-9.

8 Rosenberg SA, Packard BS. Aebersold PM et al. Use of tumorinfiltrating lymphocytes and interleukin-2 in the immunotherapy of patients with metastatic melanoma. A preliminary report. N Engl I Med 1988: 319: 1676-80.

9 Swift RI. Danpure HJ. Osman S et al. Imaging of metastatic colorectal cancer with tumour-activated killer lymphocytes. Lancet 1991: 337: 1511-12.

10 Lotze MT, Line BR. Mathisen D], Rosenberg SA. The in vivo distribution of autologous human and murine lymphoid cells grown in T cell growth factor (TCGF): implications for the adoptive immunotherapy of tumors. I Immunol 1980; 125: 1487-93.

11 Griffiith KD. Read EJ. Carrasquillo JA et al. In vivo distribution of adoptively transferred indium-111-labeled tumor infiltrating lymphocytes and peripheral blood lymphocytes in patients with metastatic melanoma. I Natl Cancer Inst 1989: 81: 1709-17.

12 Ellis TM. Creekmore SP. McMannis JD et al. Appearance and phenotypic characterization of circulating Leu $19+$ cells in cancer patients receiving recombinant interleukin 2. Cancer Res 1988:48: $6597-602$.

13 Caligiuri MA. Zmuidzinas A. Manley T] et al. Functional consequences of interleukin 2 receptor expression on resting human lymphocytes. Identification of a novel natural killer cell subset with high affinity receptors. I Exp Med 199(): 171: 1509-26.

14 Figdor CG. van Kooyk Y, Keizer GD. On the mode of action of LFA-1. Immunol Today 1990: 11: 277-80.

15 Springer TA. Dustin ML, Kishimoto TK, Marlin SD. The lymphocyte function-associated LFA-1, CD2, and LFA-3 molecules: cell adhesion receptors of the immune system. Anmu Rev Immunol 1987: 5: 223-52.

16 Basse P. Herberman RB. Nannmark Ut et al. Accumulation of adoptively transferred adherent. Iymphokine-activated killer cells in murine metastases. J Exp Med 1991: 174: 479-88.

17 Yamamura T, Fujitani Y, Kawauchi T et al. Histological evidence of natural killer cell aggregation against malignant melanoma induced by adoptive immunotherapy with lymphokine-activated killer cells. J Pathol 1989: 157: 201-4.

18 Keilholz U. Schlag P. Tilgen W et al. Regional administration of lymphokine-activated killer cells can be superior to intravenous application. Cancer 1992: 69: 2172-5.

19 Cohen PJ. Lotze MT, Roberts JR et al. The immunopathology of sequential tumor biopsies in patients treated with interleukin-2. Correlation of response with T-cell infiltration and HLA-DR expression. Am / Pathol 1987: 129: 208-16. 
This document is a scanned copy of a printed document. No warranty is given about the accuracy of the copy. Users should refer to the original published version of the material. 